\title{
Levercyste fra Østen
}
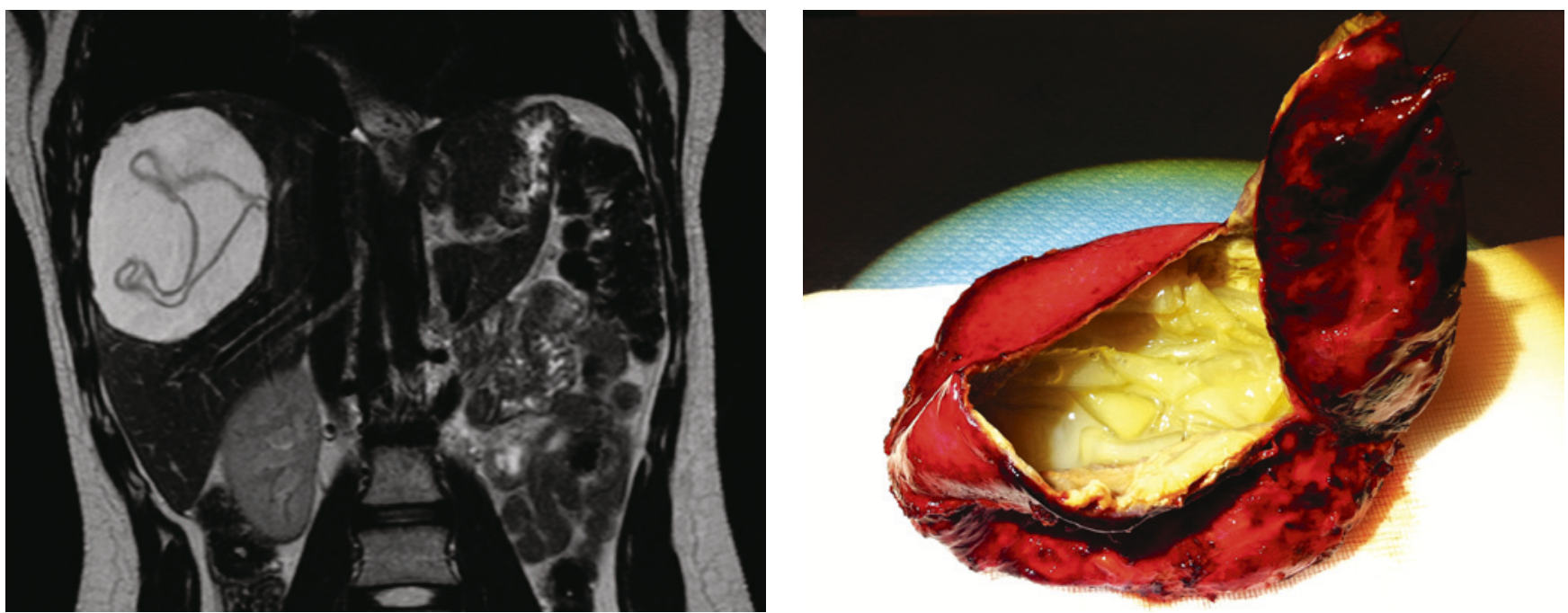

En ung jente, opprinnelig fra et sørasiatisk land, oppsøkte lokalsykehuset grunnet magesmerter. Ved utredning med CT- og ultralydundersøkelse av magen ble det påvist en $10 \times 12 \mathrm{~cm}$ stor cyste i høyre leverlapp. Serologisk prøve viste antistoffer mot ekinokokker. Pasienten fikk PAIR-behandling (punksjon - aspirasjon - injeksjon - reaspirasjon) og albendazol tabletter.

Tre år senere fikk hun magesmerter på nytt. MR-undersøkelse av leveren viste fortsatt en stor cyste i høyre leverlapp (bildet til venstre). Cysten var unilokulær med flere septa. Den ble nå kirurgisk behandlet med aspirasjon, instillasjon av hypertont saltvann og deretter ekstirpert in toto (bildet til høyre). Mikroskopi av cysteinnholdet viste Echinococcus spesies.

Human ekinokokkose er en sjelden zoonose som forekommer hos innvandrere fra endemiske områder. Den skyldes infeksjon med larver fra bendelmark av slekten Echinococcus (1). Mennesker er mellomvert og smittes ved inntak av mat som har vært i kontakt med avføring fra infiserte dyr (hovedvert) og dermed inneholder egg fra bendelmarken. Eggene klekkes i tynntarmen hos mennesker, parasitten penetrerer tarmveggen og kan spre seg til leveren via portvenen. Cystene utvikles over flere år og kan gi symptomer på grunn av trykk på organer. Leveren er affisert hos $70 \%$, lungene hos $20 \%$ og andre organer hos $10 \%$.
Diagnosen stilles ved anamnese samt radiologisk undersøkelse med ultralyd og CT eller MR. Ved Smittskyddsinstitutet i Sverige kan man påvise antistoffer mot ekinokokker i serum. Ultralydundersøkelse er viktig for klassifisering av cystene (aktive/ inaktive). Behandlingen består av albendazol og enten PAIR-behandling eller kirurgi, eventuelt observasjon hvis cystene vurderes som inaktive (1).

Pasienten har gitt samtykke til at artikkelen blir publisert.

\section{Ewa Pomianowska}

\section{Bjørn Atle Bjørnbeth}

Seksjon for lever- og pankreaskirurgi

Avdeling for gastrokirurgi

\section{Astrid Elisabeth Rojahn}

Avdeling for barnemedisin

\section{Knut Jørgen Labori}

\section{Sheraz Yaqub}

sheraz.yaqub@ous-hf.no

Seksjon for lever- og pankreaskirurgi

Avdeling for gastrokirurgi

Oslo universitetssykehus

Ewa Pomianowska (f.1970) er spesialist i generell kirurgi og lege i spesialisering i gastrokirurgi.

Forfatter har fylt ut ICMJE-skjemaet og oppgir ingen interessekonflikter.
Bjørn Atle Bjørnbeth (f. 1962) er avdelingsoverlege og spesialist i generell og gastroenterologisk kirurgi.

Forfatter har fylt ut ICMJE-skjemaet og oppgir ingen interessekonflikter.

Astrid Elisabeth Rojahn er overlege og spesialist i pediatri.

Forfatter har fylt ut ICMJE-skjemaet og oppgir ingen interessekonflikter.

Knut Jørgen Labori (f. 1965) er seksjonsoverlege og spesialist i generell og gastroenterologisk kirurgi.

Forfatter har fylt ut ICMJE-skjemaet og oppgir ingen interessekonflikter.

Sheraz Yaqub (f. 1977) er konstituert overlege og spesialist i generell kirurgi.

Forfatter har fylt ut ICMJE-skjemaet og oppgir ingen interessekonflikter

\section{Litteratur}

1. Junghanss T, da Silva AM, Horton J et al. Clinical management of cystic echinococcosis: state of the art, problems, and perspectives. Am J Trop Med Hyg 2008; 79: 301-11.

Mottatt 15.11. 2013, første revisjon innsendt 11.12. 2013, godkjent 19.12. 2013. Redaktør: Merete Kile Holtermann. 